\title{
RIAS Learning Model: a Character Education Innovation
}

\author{
Ahmad Muhlisin', Sri Sarwanti , Gentur Jalunggono 3, Arnanda Yusliwidaka \\ 4, Sukron Mazid 5, Achmad Busrotun Nufus 6
}

DOI: 10.35445/alishlah.v13i1. 520

\begin{tabular}{l}
\hline Article Info \\
\hline Keywords: \\
Character Education \\
RIAS Learning Model \\
Spiritual Attitudes \\
Social Attitudes
\end{tabular}

Kata kunci:

Pendidikan Karakter

Model Pembelajaran

RIAS

Sikap Spritual

Sikap Sosial

\begin{abstract}
Character education has not been well facilitated in every learning process; hence, several indications of low character among college students are found. This research aims to develop a new learning model based on character education to enhance students' spiritual and social attitudes. The research was a research and development by adopting Borg \& Gall's research and development procedures. The research procedures consist of the following steps: 1) Library study, 2) designing a model design, 3) learning model development, 4) expert validation, and 5) focus group discussion with users and students. Instruments used in the research include content validity and construct validity sheets of the learning model with an assessment scale score of 1-5 that ranges from (1) not feasible, (2) less feasible, (3) fairly feasible, (4) feasible, and (5) very feasible. The research results indicate that 1) characterbased learning innovation resulted in RIAS learning model with main steps of Reading, Identification, Analysis, and Self-reflection, 2) RIAS learning model has a validation score of 4.6 within a valid category; thus, it is feasible to be utilized to enhance social and spiritual attitudes. The suggested for further research is testing the effectiveness of the RIAS learning model on a wide scale and testing the effect of the RIAS learning model on problem-solving and student learning outcomes.
\end{abstract}

\begin{abstract}
Abstrak
Pendidikan karakter saat ini belum terfasilitasi dengan baik dalam setiap proses pembelajaran sehingga masih ditemukan beberapa indikasi rendahnya karakter pada mahasiswa. Tujuan penelitian untuk mengembangkan model pembelajaran baru berbasis pendidikan karakter sebagai upaya meningkatkan sikap spiritual dan sikap sosial mahasiswa. Penelitian ini merupakan penelitian dan pengembangan dengan mengadopsi prosedur penelitian dan pengembangan Borg \& Gall. Prosedur penelitian terdiri dari langkah-langkah sebagai berikut: 1) Studi kepustakaan; 2) perancangan desain model; 3) pengembangan model pembelajaran; 4) validasi pakar; dan 5) diskusi kelompok
\end{abstract}

\footnotetext{
${ }^{1}$ Universitas Tidar, Magelang, Indonesia

Email: ahmadmuhlisin@untidar.ac.id

${ }^{2}$ Universitas Tidar, Magelang, Indonesia

Email: srisarwanti@untidar.ac.id

3 Universitas Tidar, Magelang, Indonesia

Email: jalunggono@untidar.ac.id

4 Universitas Tidar, Magelang, Indonesia

Email: papierarnanda@untidar.ac.id

5 Universitas Tidar, Magelang, Indonesia

Email: sukronmazid@untidar.ac.id

${ }^{6}$ Universitas Tidar, Magelang, Indonesia

Email: busro@untidar.ac.id
} 
terfokus dengan pengguna dan siswa. Instrumen penelitian yang digunakan yaitu lembar validitas isi dan validitas konstruk model pembelajaran dengan skor skala penilaian 1-5 yang mempunyai makna (1) tidak layak; (2) kurang layak; (3) cukup layak; (4) layak; (5) sangat layak. Hasil penelitian menunjukkan bahwa 1) Inovasi pembelajaran berbasis karakter yang dihasilkan yaitu model pembelajaran RIAS dengan langkah utama Reading, Identification, Analysis, dan Self reflection; 2) Model Pembelajaran RIAS dengan skor validasi 4,6 dalam kategori valid, sehingga layak digunakan dalam pembelajaran untuk meningkatkan sikap spiritual dan sikap sosial. Saran untuk penelitian selanjutnya adalah menguji keefektifan model pembelajaran RIAS secara luas dan menguji pengaruh model pembelajaran RIAS terhadap pemecahan masalah dan hasil belajar mahasiswa.

\section{INTRODUCTION}

Human resource is the primary driver of a nation's advancement and competitiveness. The current intense competition in every field requires superior human resource quality with characters to support the nations' competitiveness. Indonesia presently experiences a crisis of national identity or character that signifies by several events. For example, massive hoax information/news and hatred speeches quickly circulate through technology and information development. It is supported by research stating that students are disseminating information to public groups without reading carefully, without understanding, and without seeing the truth first (Majid, 2019).

An observation done by the researcher in learning conducted at the Study Program of Natural Sciences Education finds several students' activities that indicate characters need to be enhanced. The activities consist of 1) students are late for a lecture; 2) students submit their assignment behind schedule; 3) students are cheating during an exam; 4) students are less capable of cooperating in a team; 5) students disagree with the heterogeneous group division system; 6) students plagiarize in working on the assignments; 7) students have less ability to analyze a problem; and 8) the learning strategies/models have not emphasized characters in learning.

Character is one's psychology, which is a personality that differentiates an individual from another. A person with character means someone who has a personality or a characteristic that becomes a trait to identify a person, an object, or an event (Anwar, 2013). A national character is a nation's identity, an accumulation or combination of characters from each citizen(Gufron, 2010). Values in the national character consist of religious, nationalist, integrity, independence, and gotong royong (mutual assistance) (Perpres Nomor 87 tahun 2017 tentang Pendidikan Karakter, 2017).

Efforts in building and maintaining the nation's character of Indonesian citizens require the implementation of national character education by strengthening character education in learning, especially for young generations. It could be applied through the reinforcement of spiritual and social attitudes that include religious values, honesty, tolerant, disciplines, work hard, creativity, independence, democratic, curiosity, nationality, patriotism, appreciating achievement, communicative, peace-loving, fond of reading, caring for the environment, social awareness, and responsibility (Berliana et al., 2018).

Character is a pivot in education as it is the end goal of a learning process. Character building could undergo a learning process that integrates character values in each learning step. Based on research, learning in improving character can be through modelling or real examples in everyday life (Marzuki, 2012). It can also be improved by understanding the importance of character during the learning process (Yuningsih et al., 2019). Therefore, it is necessary to conduct research aiming at developing a character-based learning model to enhance students' spiritual and social attitudes facilitated in each step of the learning process. Integration of character values is proven effective in enhancing learners' characters (Sulasmono et al., 2017); (Muswara \& Zalnur, 2019).

This study develops a learning model that integrates the character of spiritual and social attitudes that are accommodated in the unity of the learning process. The difference or novelty in 
Al- Ishlah: Jurnal Pendidikan, June 2021, 13 (1), Pages 660-667

Ahmad Muhlisin, Sri Sarwanti, Gentur Jalunggono, Arnanda Yuswilidaka, Sukron Mazid, Achmad Busrotun Nufus

this learning model is that students are asked to connect or conduct a self-assessment of spiritual and social attitudes that have been carried out in everyday life related to the topic or study being studied.

\section{METHODS}

\section{Research Design}

The research was a research and development by adopting Borg dan Gall (2003) research and development procedures. It aimed to develop a character-based learning model to enhance students' spiritual and social attitudes. The research steps consisted of 1) library study, in this steps, reviewing learning tools, observing learning processes, reviewing research results related to the learning process that can improve student character, and reviewing the literature on social systems in learning, 2) designing a model design, the activity is making a prototype of learning design which is integrating characteristics value, 3) learning model development, this activity focuses in compiling all learning process will be carried out, 4) expert validation, in this step, asking for assessment from two experts, characteristic learning's expert and biology or natural science's expert, and 5) focus group discussion with users and students, the activity done in this steps is discussing to gain suggestions from the lecturer in natural science education study program and students. The research took place at Universitas Tidar.

\section{Instruments}

The instruments in the research comprise content validity and construct validity sheets of the learning model utilized to measure the validity level of the character-based learning model. The validation instruments accommodated assessment aspects that formed the basis of a learning model, namely: 1) learning model development goals, 2) supporting theories, 3) learning syntax, 4) social system, 5) reaction principle, 6) supporting system, and 7) instructional effects and nurturant effects. The assessment scale score in each aspect was 1-5 that interpreted as (1) not feasible, (2) less feasible, (3) reasonably feasible, (4) feasible, and (5) very feasible for each aspect. The data was obtained through a validation sheet used by the expert and analyzed by averaging each aspect asked and making an overall average on all aspects of the validation of the learning model.

\section{FINDINGS AND DISCUSSION}

The character-based learning model development to enhance students' spiritual and social attitudes generated a learning model known as the RIAS learning model. The model is a learning model that consists of the following main steps: Reading, Identification, Analysis, and Selfreflection. Learning activities in the RIAS model are elaborated in Table 1.

\section{Table 1. Learning Activities in the RIAS Learning Model}

\section{Instructional Design of RIAS}

\section{Learning procedures}

\footnotetext{
Phase One: Introduction

- $\quad$ Students and lecturers pray before the learning starts according to their respective religions and belief.

- Lecturers check students' presence

- Lecturers explain the learning objectives and steps

Phase Two: Main Activities

Reading

Students independently read topics or study materials to be learned

Identification

Students identify essential matters in a group, such as problems or phenomena related to topics or content being studied.

Analysis

- $\quad$ Students, in a group, analyze problems or phenomenon related to topics or content beings studied.

- Students create a solution to solve problems or phenomena related to topics or content beings studied.
} 


\section{Self-reflection}

- $\quad$ Students present their analysis results to other students.

- Students conduct self-reflection regarding the spiritual and social attitudes performed during the learning process. Students link the topics or content to the spiritual and social attitudes in daily life.

- Students convey the self-reflection results to other students

Phase Three: Closing

- $\quad$ Lecturers facilitate students to conclude the learning conducted

- Lecturers confirm the learning process carried out

- Lecturers provide follow up guidance for the following activities

- $\quad$ Students and lecturers pray according to their respective religion and belief

\section{Expert Validation Results and Focus Group Discussion}

These activities measured the validity level of the RIAS learning model developed to enhance the spiritual and social attitudes that reflected characters. The validation results by character education experts are presented in Table 2.

Table 2. Content Validity Results by Character Education Experts

\begin{tabular}{llcc}
\hline No & \multicolumn{1}{c}{ Assessment Aspect } & Average Score & Category \\
\hline 1. & Objectives & 5.0 & Valid \\
2. & Supporting Theories & 5.0 & Valid \\
3. & Learning syntax & 4.5 & Valid \\
4. & Social system & 4.5 & Valid \\
5. & Reaction principle & 4.6 & Valid \\
6. & Supporting system & 5.0 & Valid \\
7. & Instructional impacts and nurturant effects & 4.1 & Valid \\
\multicolumn{1}{r}{ Average } & 4.6 & Valid \\
\hline
\end{tabular}

Content validation results based on Table 2 obtained an average value of 4.6 within a valid category; hence, it could be inferred that the RIAS learning model is feasible to implement in developing spiritual and social attitudes. Next was construct validation to identify the RIAS learning model theories towards its suitability regarding theories and learning model development objectives. The construct validation results are displayed in Table 3.

Table 3. Construct Validity Results from Character Education Experts

\begin{tabular}{|c|c|c|c|}
\hline No & Assessment Aspect & Average Value & Category \\
\hline 1. & $\begin{array}{l}\text { Conformity between learning model stages and } \\
\text { objectives to be achieved is not contradictory. }\end{array}$ & 5.0 & Valid \\
\hline 2. & $\begin{array}{l}\text { The linkage between the supporting theories and } \\
\text { learning characteristics of Biology study material } \\
\text { supports each other. }\end{array}$ & 5.0 & Valid \\
\hline 3. & $\begin{array}{l}\text { Principle understanding of the supporting theories is } \\
\text { not contradictory to the learning objectives and } \\
\text { characteristics. }\end{array}$ & 5.0 & Valid \\
\hline 4. & $\begin{array}{l}\text { The linkage of each learning model stage internally } \\
\text { supports each other. }\end{array}$ & 5.0 & Valid \\
\hline 5 . & $\begin{array}{l}\text { Students and lecturer activities in each learning stage } \\
\text { in the learning model are interrelated. }\end{array}$ & 5.0 & Valid \\
\hline 6. & $\begin{array}{l}\text { Learning source utilization for achieving objectives is } \\
\text { mutually supportive. }\end{array}$ & 4.5 & Valid \\
\hline 7. & $\begin{array}{l}\text { The interaction pattern between students and } \\
\text { lecturers supports each other. }\end{array}$ & 5.0 & Valid \\
\hline 8. & $\begin{array}{l}\text { Lecturer behavior to motivate and guide students } \\
\text { illustrates in the learning model stages. }\end{array}$ & 4.5 & Valid \\
\hline & Average & 4.6 & Valid \\
\hline
\end{tabular}


Table 3 indicates that character education experts' theoretical construct validation results resulted in an average value of 4.6 with a valid category; thus, the RIAS learning model concept theoretically could enhance spiritual and social attitude characters. As regards theoretical study, the RIAS learning model bases on constructivism, collaborative, and connectivism. It is constructivismbased since it facilitates students to build their knowledge according to their previous experiences. It is in accordance with (Crotty's, 2012) constructivism principles in learning, namely: 1) knowledge is actively built by students, 2) pressure in the learning process is on students, 3) teaching is helping students to study, 4) pressure in the learning process is more towards the process instead of the final results, 5) the curriculum emphasizes student participation, and 6) teacher is a facilitator. Research results by (Clair, 2001); (Samaresh, 2017); (Chidinma \& Department, 2018) stated that constructivism-based learning could improve learners' concept mastery and critical thinking.

The RIAS learning model also bases on collaboration indicated by group cooperation in identifying and analyzing a problem. Collaborative learning fosters social attitudes, such as a corporation, mutual assistance, mutual respect, and learning objectives. It corresponds to studies by (Ekimova \& Kokurin, 2015); (Chatterje\&Correia, 2020) that collaborative cooperation learning can improve cooperation and self-confidence.

Besides constructivism and collaboration, the RIAS learning model also bases on connectivism. It is by considering that the current era learning process affects information and technology and facilitates the RIAS learning model from the reading activity of a topic or content accessible online. Similar to (Siemens, 2004); (Saz et al., 2016), the current era learning process is influenced by information technology development as its support; hence, it achieves the learning objectives and enhances learners' curiosity.

The RIAS learning model met the learning model elements stated by (Joyce et al., 2011). The learning model has five basic elements: syntax, social system, reaction principles, support system, and instructional and nurturant effects. The elements are further elaborated in Table 4.

\section{Table 4. RIAS Learning Model Elements}

\begin{tabular}{|c|c|c|}
\hline No & $\begin{array}{l}\text { Learning model } \\
\text { elements }\end{array}$ & RIAS learning model elements \\
\hline 1. & Syntax & $\begin{array}{l}\text { The learning model syntax consists of Reading, Identification, Analysis, } \\
\text { and Self-reflection. }\end{array}$ \\
\hline 2. & Social system & $\begin{array}{l}\text { The social system reflects in group discussion activities that facilitate each } \\
\text { student to solve problems in topics being studied. }\end{array}$ \\
\hline 3. & Principles of reaction & $\begin{array}{l}\text { The learning activities are student-centred, and the lecturer acts as a } \\
\text { motivator and facilitator in the learning process. }\end{array}$ \\
\hline 4. & Support system & $\begin{array}{l}\text { The learning sources include references or information related to topics } \\
\text { being studied, learning media, facilities, materials, and tools needed for } \\
\text { the learning. }\end{array}$ \\
\hline 5. & $\begin{array}{l}\text { Instructional and } \\
\text { nurturant effects }\end{array}$ & $\begin{array}{l}\text { Students could directly affect the learning objectives; therefore, learners } \\
\text { could apply the concept learned daily. The nurturant effects are the spiritual } \\
\text { and social attitudes }\end{array}$ \\
\hline
\end{tabular}

The RIAS learning model affects the learning objectives and enhances spiritual and social attitudes due to its activity that consists of Reading, Identification, Analysis, and Self-reflection. The spiritual attitudes comprise carrying out religious teachings under their respective beliefs, be grateful, answer greeting, and maintain a good relationship between the students and students and lecturers. The social attitudes include being honest, discipline, responsible, polite, confident, and careful to others. RIAS learning model relationship with spiritual and social attitudes is illustrated in Figure 1. 
Reading facilitates students to be independent, responsible, discipline, hard working, lifelong learners, and curiosity

Identification faciltates students to cooperate, and help and respect each other
Analysis facilitates students to care and maintain a good relationship with others
Self-reflection facilitates students to be honest, polite and confident

Figure 1. Relationship of RIAS Learning Model and Spiritual and Social Attitude Characters

The reading stage carried out by students in the RIAS learning model aims to facilitate them to prepare independently and intrigue curiosity towards problems or phenomena on topics being studied. (Zahoor-ul-Haq et al., 2019) stated that students' activity to search for information provides important influences in concluding and the underlying reasons and increases activities in the learning process. The activity allows students to ask themselves about the weaknesses or things required to understand a problem or phenomena being studied.

Following the reading activity is identification and analysis activities. These activities facilitate students to identify and analyze problems or phenomena related to topics or content being studied. It permits students to be oriented towards everyday problems, thus enhances characters(Irawatie et al., 2019). Moreover, learning becomes more meaningful. These activities carry out in a heterogeneous group between the students. Social interaction in the group allows students to exchange ideas and diversity of viewpoints and offers opinions between the group members. Social interaction in the group work process is in line with (Rahmawati \& Yusuf, 2008); (Creighton \& Szymkowiak, 2014) that social interaction in group learning could facilitate exchanging information and enhancing learning outcomes achievement. The learning process activities in the RIAS learning model require individual and group responsibility for its learning success. It is believed to enhance independent character, as stated by (Sari, 2013) research, that activities that facilitate individual and group responsibility can increase independence in learning.

The last stage in the RIAS learning model is self-reflection. Students present their analysis results to other students in this activity, and they self-reflect on the spiritual and social attitudes carried out during the learning process. In other words, students connect topics or contents to the spiritual and social attitudes in everyday life. The essence of character education lies in the selfreflection that philosophically defines as reflects or assesses ourselves on activities that have been conducted in the learning process and/or links topics learned to character values applicable by learners in daily life.

The self-reflection activity is believed to enhance characters in spiritual and social attitudes as students are trained to be honest in conveying activities that have been done during learning. (Mathew et al., 2017) assert that reflective activity is an activity to observe what has been done to improve character building to establish professional human resources. Likewise, (Fisher et al., 2017); (Baidhowi, 2018) explains that reflective activity is capable of improving honesty values, reflection or introspective abilities, and self-control; hence, it is applicable as self-improvement in the future 


\section{CONCLUSION}

Innovation of national character-based learning generated in the research was a RIAS learning model consisted of main steps, namely: Reading, Identification, Analysis, and Self-reflection. The RIAS learning model is feasible to enhance spiritual and social attitudes, and it is an innovation in character education. This study recommends that learning syntax and the importance of character education must be explained to students before implementing the learning process. Moreover, in the Biology or science learning process, students must be provided with an explanation of characters connected in learning about phenomenon or biology or science studies. It is intended so that students could link the character education to a study learned in the class.

Further research and development include implementing the RIAS learning model in biology or science by integrating the problem-based learning system. College students or students could solve daily problems by referring to characters of spiritual and social attitudes. The RIAS learning model will be tested in the following research to all levels of education in Indonesia, from primary school to higher education. The field of study used in the RIAS learning model implementation will include social language education

\section{REFERENCES}

Anwar, H. S. (2013). Membangun Karakter Bangsa. At-Ta'dib, 8(1), $1-17$. https://ejournal.unida.gontor.ac.id/index.php/tadib/article/view/511

Baidhowi, M. R. (2018). Instrumen Penilaian Sikap Sosial (Studi Penilaian Sikap Sosial Pada Mata Pelajaran Fikih Di Jurusan Tehnik Dan Bisnis Sepeda Motor Smk Muhammadiyah 1 Patuk). Edudeena, 2(1), 41-56. https://doi.org/10.30762/ed.v2i1.518

Berliana et.al. (2018). Penguatan Karakter Kebangsaan Peserta Didik Di Sekolah Indonesia (Singapura). 3(1), 204-216.

Chatterje\&Correia (2020). Online Students' Attitudes Toward Collaborative Learning andSense of Community. American Journal of Distance Education, 34 (1), 53-68.

Chidinma, W. C. and O. A., \& Department. (2018). Mastery Learning Approach Versus Constructivist-Based Learning Approach On Senior Secondary School Students' Academic Achievement In Biology. 6(1), 1-10.

Clair, B. (2001). A Study of the E ects of Constructivist Based vs. Traditional Direct Instruction on 8th Grade Science Comprehension. Doctor of Philosophy (PhD), Dissertation, , old Dominion University.

Creighton, S., \& Szymkowiak, A. (2014). The Effects of Cooperative and Competitive Games on Classroom Interaction Frequencies. Procedia - Social and Behavioral Sciences, 140(01382), 155-163. https://doi.org/10.1016/j.sbspro.2014.04.402

Crotty, K. (2012). Educational Theory. Waterford Women's Centre. (Online) www.waterfordwomenscentre.com

Ekimova, V., \& Kokurin, A. (2015). Students' Attitudes Towards Different Team Building Methods. Procedia - Social and Behavioral Sciences, 186, 847-855. https://doi.org/10.1016/j.sbspro.2015.04.157

Fisher, D., Yaniawati, P., \& Kusumah, Y. S. (2017). The use of CORE model by metacognitive skill approach in developing characters junior high school students. AIP Conference Proceedings, 1868(August). https://doi.org/10.1063/1.4995137

Gufron. (2010). anik gufron-Integrasi Nilai-nilai Karakter Bangsa pada Kegiatan Pembelajaran(1).

Irawatie, A., Iswahyuni, I., \& Setyawati, M. E. (2019). Education Learning Development of Character Education-Based State Defense. International Journal of Multicultural and Multireligious Understanding, 6(2), 27-42. https://ijmmu.com/index.php/ijmmu/article/view/602

Joyce, B., Weil, M., and Calhoun, E. (2011). Model of Teaching Model-Model Pengajaran. Edisi Kedelapan. Yogyakarta: Pustaka Pelajar.

Majid, A. (2019). Fenomena Penyebaran Hoax dan Literasi Bermedia Sosial Lembaga Mahasiswa Universitas Muslim Indonesia. Jurnal Komodifikasi, 8, 228-239. http://journal.uinalauddin.ac.id/index.php/Komodifikasi/article/view/11329

Marzuki. (2012). Intergating character education in the teaching and learning at school. Jurnal Pendidikan Guru Sekolah Dasar, 2(1), 33-44. 
Mathew et al. (2017). Reflective practice: as a means to teacher development. Journal of the Korean Physical Society, 59(6), 3356-3362.

Muswara, A., \& Zalnur, M. (2019). Design of Character Building for Learners in Boarding Schools in West Sumatera. Khalifa Journal of Islamic Education, 3(1), 1-16. https://core.ac.uk/download/pdf/230568464.pdf

Perpres Nomor 87 tahun 2017 tentang Pendidikan Karakter. (2017). Peraturan Presiden Republik Indonesia Nomor 87 Tahun 2017 Tentang Penguatan Pendidikan Karakter. 9(195), 164-178. https://setkab.go.id/inilah-materi-perpres-no-87-tahun-2017-tentang-penguatanpendidikan-karakter/

Rahmawati, I., \& Yusuf, A. (2008). Cooperative Play Affects Social Interaction of Children who have Introvert Personality. Jurnal Ners, 5(1), 38-48.

Samaresh, A. (2017). Effectiveness of constructivist approach on academic achievement in science at secondary level. Educational Research and Reviews, 12(22), 1074-1079. https://doi.org/10.5897/err2017.3298

Sari, N. (2013). *Darini Graduated in 25 June 2013 from English Education Study Program of Indonesia University of Education. 1(1), 30-42.

Saz, A., Engel, A., \& Coll, C. (2016). Introducing a personal learning environment in higher education. An analysis of connectivity. Digital Education Review, 29, 1-14. https://doi.org/10.1344/der.2016.29.1-14

Siemens, G. (2004) Connectivism: A Learning Theory for the Digital Age. http://www.elearnspace.org/Articles/connectivism.htm.

Sulasmono, P., Ekosiswoyo, R., \& Sugiyo. (2017). the Integration of Local Cultural Wisdom Values in Building the Character Education of Students. International Journal of Education and Research, 5(6), 151-162.

Yuningsih et al. (2019). Pembelajaran Bahasa Indonesia. Integrasi Pendidikan Karakter Pada Pembelajaran Bahasa Indonesia Di Smp Negeri 2 Sawan, 9(4), 71-77.

Zahoor-ul-Haq, Khurram, B. A., \& Bangash, A. K. (2019). Development of Reading Skill through Activity Based Learning at Grade-VI in Khyber Pakhtunkhwa. Bulletin of Education and Research, 41(1), 85. https://search.proquest.com/scholarly-journals/development-readingskill-through-activity-based/docview/2333512628/se-

2?accountid=13828\%oAhttp://find.shef.ac.uk/openurl/44SFD/44SFD_services_page?url_ve $\mathrm{r}=$ Z39.88-2004\&rft_val_fmt=info:ofi/fmt:kev:mtx:journal 